\title{
BIBLIOGRAPHY
}

\section{LEXICA AND DICTIONARIES}

Brockelmann, C., Lexicon syriacum, 2nd ed. Halle, 1928.

Koehler, L., Baumgartner, W., and Stamm, J. J., The Hebrew and Aramaic Lexicon of the Old Testament. Translated and edited by M. E. J. Richardson; Leiden: Brill, 1994-1999. (HALOT)

Payne Smith, J., A Compendious Syriac Dictionary. Oxford: Clarendon Press, 1896.

Payne Smith, R., Thesaurus syriacus. Oxford: Clarendon, 1879.

Sokoloff, M. and Brockelmann, C., A Syriac Lexicon: A Translation from the Latin: Correction, Expansion, and Update of C. Brockelmann's Lexicon Syriacum. Piscataway, NJ: Gorgias Press, 2009.

\section{REFERENCES}

Brock, Sebastian P., 'Genesis 22 in Syriac Tradition', in Mélanges Dominique Barthélemy: Études Bibliques offertes à l'occasion de son 60 e anniversaire. Edited by Casetti, Pierre and Keel, Othman and Schenker, Adrian. Orbis Biblicus et Orientalis 38. Göttingen:Vandenhoeck \& Ruprecht, 1981, 1-30.

Dyk, Janet W. and van Keulen, Percy S. F., Language System, Translation Technique, and Textual Tradition in the Peshitta of Kings. MPIL 19. Leiden/Boston: Brill, 2013.

Heal, Kristian S., 'Tradition and Transformation: Genesis 37 and 39 in Early Syriac Sources'. Ph.D. dissertation, University of Birmingham, 2008.

Jansma, Taeke and Koester, Marinus D., eds., The Old Testament in Syriac according to the Peshitta Version. Part I, fasc. 1: Preface; Genesis-Exodus. Leiden: Brill, 1977.

Kooij, Arie van der, 'Peshitta Genesis 6: 'Sons of God'-Angels or Judges', Journal of Northwest Semitic Languages 23:1 (1997): 43-51.

Lund, Jerome A., 'The Influence of the Septuagint on the Peshitta: A ReEvaluation of Criteria in the Light of Comparative Study of the Versions in Genesis and Psalms'. Ph.D. dissertation, The Hebrew University of Jerusalem, 1988. 
Lund, Jerome A., 'Genesis in Syriac', in The Book of Genesis: Composition, Reception, and Interpretation. Edited by Evans, Craig A. and Lohr, Joel N. and Petersen, David L. Supplements to Vetus Testamentum 152. Leiden/Boston: Brill, 2012, 537-560.

Levine, Étan, 'The Syriac Version of Genesis IV 1-16', Vetus Testamentum 26:1 (1976): 70-80.

Maori, Yeshayahu, 'The Relationship between the Peshitta Pentateuch and the Pentateuchal Targums', in Targum Studies. Vol. 2: Targum and Peshitta. Edited by Flesher, Paul V.M. South Florida Studies in the History of Judaism 165. Atlanta, Georgia: Scholars Press, 1998, 57-73.

Romeny, Robert Bas ter Haar, 'Techniques of Translation and Transmission in the Earliest Text Forms of the Syriac Version of Genesis', in The Peshitta as a Translation: Papers Read at the II Peshitta Symposium Held at Leiden, 19-21 August 1993. Edited by Dirksen, Piet B. and van der Kooij, Arie. Monographs of the Peshitta Institute Leiden 8. Leiden: Brill, 1995, 177-185.

Weitzman, M. P., The Syriac Version of the Old Testament: An Introduction. Cambridge: Cambridge Univ. Press, 1999. 